\title{
Policy Design for Optimizing the Hydropower Generation Potential of Maithon Multi-purpose Reservoir System
}

\author{
Priti Sagar, Prabeer Kumar Parhi, B. Bharti
}

\begin{abstract}
It is proposed to develop an optimal operating policy for the Maithon multi-purpose reservoir system,situated at Maithon, which is approximately $48 \mathrm{~km}$ from the district of Dhanbad (Jharkhand), India.The present objective is to maximize hydropower generation subjected to reservoir mass balance, release, storage,reservoir-drawdown level, overflow,maximum flood zone space,maximum and minimum storage constraints under three different dependable inflow conditions namely $50 \%, 70 \%$ and $90 \%$.The storage curves also been derived after analyzing the various policies and was observed to be persistent with that of demand requirements. The derived policy is capable of producing maximum annual hydropower of 133394.43 MWh,103015.14 MWh and 61782.77MWh for 50\%, $70 \%$ and $90 \%$ dependable inflow conditions respectivelyagainst theexisting generated values of hydropower as 102958.3 MWh which has been averaged over last 10 years.Further the firm hydropower power values obtained under $50 \%, 70 \%$ and $90 \%$ dependable inflow conditions are 5.773 MW, 3.421 MW and 2.67 MW respectively.In this study the potential ofhydropower energy production of the reservoir system is explored extensively, and a trade-off between reservoir release especially for irrigation purpose andmaximum energy production has been established for the use of various stakeholders as well as managers of reservoir operations .
\end{abstract}

Keywords: Optimal-operation-policy, Optimal hydropower generation, LINGO, Dependable inflow, Maithon reservoir

\section{INTRODUCTION}

Hydropower is one of the abundantsourceof renewable energy, accountsfor about 17 percent of the world's electricity (International Energy Agency Report on Renewables, 2017-2023). It is certainlyone of the promising solutions for clean and green energy sources in the world to meet a country's rapidly increasing energy demands.The production of hydropower and the release of irrigation water are two major stakeholders of any large multi-purpose reservoir. Sometimes it is found that the aforementioned priorities are complementary to one another. Many dams in India have hydropower plants, and the generation of hydropower is considered as one of the significant component of reservoir operations, particularly for a large scale reservoir system.

Revised Manuscript Received on December 30, 2019

* Correspondence Author

Priti Sagar, PhD Research Scholar, Department of WEM, Central University of Jharkhand, Ranchi, India.

Dr. Prabeer Kumar Parhi, Assistant Professor, Department of WEM, Central University of Jharkhand, Ranchi,

Dr. Birendra Bharti, Assistant Professor, Department of WEM, Central University of Jharkhand, Ranchi, India

(C) The Authors. Published by Blue Eyes Intelligence Engineering and Sciences Publication (BEIESP). This is an open access article under the CC BY-NC-ND license (http://creativecommons.org/licenses/by-nc-nd/4.0/)
Optimizing the operatingpolicies of such reservoirs serving both of the conflicting goals is found to be difficult, especially if the development of hydropower is not an incidental event. As the hydropower release is nonconsumptive in nature, the released water can be further utilized in the downstream site for other purposes. Electricity demand at present time is on peak and therefore alternate mode of generation of electricity is highly desirable to maximize the hydropower production wherever it is possible. In India there is a high potential for hydropower production from surface water reservoirs, therefore, arising a need for developing effective operational policies to maximize the hydropower benefits. Along with this the focus should be on exploring the additional potential sources of hydropower.Further, the generation of hydropower for a multi-purpose reservoir network serving different objectives likecontrol of flood, fulfillment of irrigation needs, hydroelectric power generation, river navigation, water supply and other recreational activities etc. is considered as a complex task as these goals are contradictory in nature for which a comprehensive analysis is needed. Mays and Tung (1992) identified the different applications of optimization techniques during the planning, development and operational process of water resources.Singh (2012) has implemented the application of optimization techniques in conjunctive planning and many other fields such as groundwater and seawater intrusion, irrigation dam management, optimum plant pattern, reservoir system activity management, resource management, and solid waste managementin different climatological regions. A wide range of reservoir operation techniques as well as models has been derived, applied and updated from time to time by different research groups working in the field of reservoir operations. But, in last few decades, the application of outdated technology and inefficient operating policies of existing reservoir systemshas been immerged as a critical issue and repeatedly raised by many scientific groups as well as researchers working in this domain(e.g. Guariso et al., 1986; Oliveira and Loucks, 1997; Chang, 2003).For the planning and management of water resources, a wide range of reviews along with applications of different optimization techniques are available in various literature(Yeh, 1985; Wurbs, 1993; Rani and Moreira, 2009).Barros et al. (2003) introduced the application of SISOPT (Sequential Interactive System Optimization), model in order to manage and enhance the operation mechanism of the Brazilian hydropower system. 
The basic model was devised using the Non-linear programming (NLP) model.Majumdar and Nirmala (2007) applied a stochastic optimization tool namely Bayesian Stochastic Dynamic Programming (BSDP) tool to the Stage IKalinadi Hydroelectric Project (KHEP), in the state of Karnataka, India, for hydropower generation by taking into consideration the forecast uncertainty along with uncertainty in inflow.Liu et al. (2008) applied anintegrated approach in order to solve the problem of multi objective reservoir systemby combining linear approximation method to the STHOS(Short Term Hydropower Optimal Scheduling). Theproposed modelin this study was found to be efficient enough in handling the complexity of the objectives and constraints of STHOS model.Moosavian et al. (2008) developed a multi-objective optimization model based on non-linearprogramming model and applied to serial and parallel hydroelectric power plants in order to find out the optimal annual scheduling for control of power generation. Barros et al. (2009) presentedthe application of HIDROTERM DSS (Hydrothermal Decision Support System) system to the Itaipu hydropower plant in order to analyze theupstream storage reservoir's impact onthe generation of the hydroelectric power.HIDROTERM DSS is basically an optimization model and based on NLP (Non Linear Programming) Model. Asignificant impact on the hydropower production of Itaipu hydropower plant was noted because of the upstream storage reservoir.Arunkumar and Jothiprakash(2012) optimized the Koyna reservoir operation policies to maximizethe hydroelectric power generation of the reservoir system, by employing the NLP (Non Linear Programming) model. In this study three different dependable inflow scenarios were choosen in order to analyze the hydropower production potential of the reservoir. Sharif and Swamy (2014) presented the LINGO (Language for Interactive General Optimizer) model's development and application to optimize the operating policy of a multi-purpose reservoir network. Inthis studythe basic problem of four reservoir (Larson, 1968) incorporating linearobjective function and a reformed problem with nonlinear objective function were explained and solved by employing the LINGO based interface. The performance of the LINGO model was evaluated and comparedby solving both the problems using Discrete Differential Dynamic Programming (DDDP) also. Results showed that over the DDDP model, the LINGO model was found to be more resilient and remarkable in terms of execution time. An additionalasset of the LINGO model is that it can be applied to anynetwork of reservoirs with minimal variation.M.H. et al. (2016) presented a case study of Mahadhayi River Project Karnataka for the maximization of the net benefits in the system from power generation and the release pattern that to be adopted in order to maximize energy generation subject to various constraints.Parsa et al. (2017) applied LINGO software packagefor the calculation of maximum volume of the Karun-IV reservoir system. The results of this study showed a very good compliance with optimal values and historical observations.Anand et al. (2018) optimized the Ganga river basin's operating policy by applying the integrated framework of Genetic Algorithm (GA) and SWAT (Soil and Water Assessment Tool) model.This study wascarried out to minimize the yearly sum of square deviation from desired storage capacity and the releaserequired for irrigation purposes.The results of this study showed that, the operational policies derived using
Genetic Algorithm were found to bemore promising and viable compared to that of policies derived using SWAT model.Even though various techniques are available for the domain of reservoir optimization, the nonlinearity in objective functions and constraints makes the process of optimizing operational policies for hydropower generation an intricate task. Although, a large number of computational programming techniques as well as hydrological models have been developed by various researchers in order to find out the best operating policies for water resources system, a standard approachthat can handle problems in their general form has not yet been established. Most of these techniques work satisfactorily on the issues for which they are being developed and bounded to either some specific constraints boundary or some time frame or space frame.Hence, the present study has been carried out to optimize the hydropower generation of a multipurpose reservoir system, while meeting all other demands (domestic, industrial, irrigation and environmental flow etc.) by the reservoir simultaneously at different dependable inflow conditions, using the software package LINGO (Language for Interactive General Optimizer),which is not available in the literatures till now. The above developed model could be further extended to optimize power output for another water reservoir system in future also.

\section{MATERIALS AND METHODS}

\section{A.Study Area}

Maithon multi- purpose reservoir system issituated at Maithon, which is at the radial distance of $48 \mathrm{~km}$ from the district of Dhanbad (Jharkhand), India. The reservoir is built on the River Barakar, a tributary of Damodar River, catchment area of $6294 \mathrm{~km} 2$.It is $4789.0176 \mathrm{~m}(15,712$ $\mathrm{ft})$ long and $50.292 \mathrm{~m}(165 \mathrm{ft}$.) high. The prime motive behind the construction of this dam was flood control and hydropower generation for the states of Jharkhand and West Bengal.In India the river Damodar has been categorized as a seasonal river, as $82 \%$ of the total storage is filled up by rainfall during the monsoon season (July to September).During filling period (1st June to 31st October) of the reservoir, rainwater is get accumulated in the reservoir and is used for irrigation purpose, hydroelectric power generation and other recreational activities by the downstream areas of Burdwan.Fig. 1 describes the details of Damodar Basin.

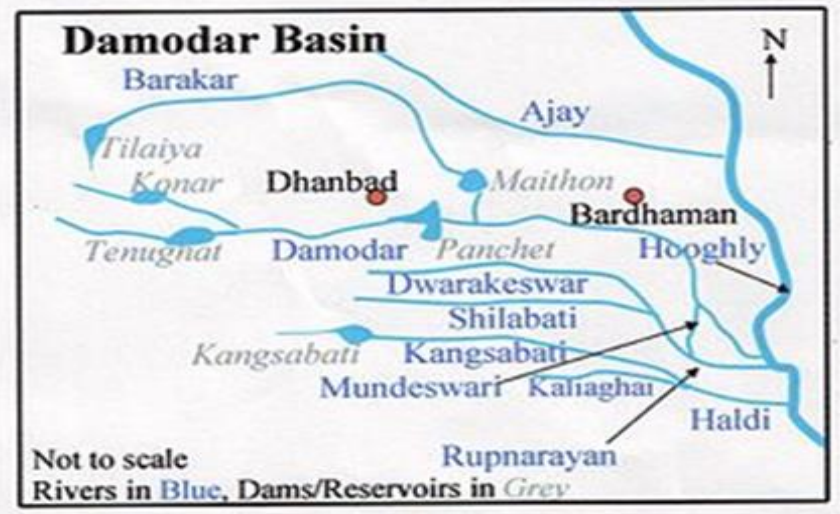

Fig.1. Index Map of Damodar Basin

(*Source: Damodar Valley Reservoir Regulation Manual(2017)) 
Maithon Hydroelectricity Power Station (MHPS) is situated on the river Barakar which is $12.9 \mathrm{~km}$ (approx.) above its convergence with Damodarriver, near the frontier of Burdwan district (West Bengal) and dhanbad district (Jharkhand). MHPS is installed 100 feet below the water level in the left bank of the river Damodar, making it the first of its kind in India. The total hydropower generating capacity of the power station is $60 \mathrm{MW}$ with 3 units of 20 MW each. Table-I shows the salient features of Maithon Dam.

Table- I: Salient Features of Maithon Dam

\begin{tabular}{|c|c|}
\hline Particulars & Maithon Dam \\
\hline Name of River & Barakar \\
\hline Location & $\begin{array}{l}\text { Lat: } 23^{\circ} 47^{\prime} \mathrm{N} \text {, } \\
\text { Long: } 86^{\circ} 49^{\prime} \mathrm{E}\end{array}$ \\
\hline Drainage Area (Sq. km) & 62937.7 \\
\hline MDDL (m.) & 132.588 \\
\hline Conservation Level (m) & 146.304 \\
\hline Max. Flood Control Level (m) & 150.876 \\
\hline Water Surface Area at Max Flood Control Level (Sq.km) & 99.63 \\
\hline Capacity at Max. Flood Control Level (MCM) & 868.039 \\
\hline Power Output & $3 \times 20 \mathrm{mw}$ \\
\hline Type of Turbine & Horizontal shaft Francis \\
\hline
\end{tabular}

*Source: Damodar Valley Reservoir Regulation Manual(2017)

\section{B. Model Description}

In this paper a LINGO (Language for Interactive General Optimizer) based integrated framework has been presented for maximum hydropower generation and water release for various usesof the Maithon multi-purpose reservoir system.This integrated framework is very easy to work on, as it integrates the three fundamental layers viz. Base layer, co-ordination layer \& user layer into one framework which requires very basic knowledge of mathematical modeling with no or negligible experience required. The same framework can be implemented to other hydel power stations with negligible effort because of it's unique feature of simple Decision Support System (DSS). LINGO provides very user friendly features viz. multi-threading capability and vast model solving capability for its users (Si, et al., 2018).Using this framework, the hydropower generation of Maithon dam is evaluated and optimizedduring the periodof 1981 to 2016.

\section{Model Formulation}

The true potential of a hydel power plant is basically determined by two main factors, hydraulic head availability and the rate of flow through the turbine. Mr. Loucks et al. (1981) explained about hydel power generation from a reservoir mainly depends on installed capacity of plant, flow rate through the turbine, number of hours being operated and average effective storage head. Thus, for any " $t$ " time period, the hydel power production (HPt) (Vedula and Mujumdar; 2005) in terms of MWh/year is given as:

$\mathrm{HP}_{\mathrm{t}}=\sum_{t=1}^{12}\left[0.001 \times 2725 \times \eta \times\left(\left(\frac{\mathrm{H}_{\mathrm{t}}+\mathrm{H}_{\mathrm{t}+1}}{2}\right) \times \mathrm{R}_{\mathrm{t}}\right)(1.1)\right.$

Where HPtisthe monthly hydropower production through the reservoir, $\eta$ is combined turbine and generation efficiency of the plant, $H_{t}$ is the head available to the turbine at the beginning of the month ' $\mathrm{t}$ ', $\mathrm{H}_{\mathrm{t}+1}$ is the head available to the turbine at month-end " $\mathrm{t}$ " or upcoming month's beginning " $t+1 ", R_{t}$ is the release made through the penstock.
The main purpose of this study is to maximize the hydel power generation of powerhouseon monthly basis. It is expressed as:

$\operatorname{Maximize}(\mathrm{Z})=\sum_{t=1}^{12}\left[\mathrm{HP}_{\mathrm{t}}\right](1.2)$

Where, $\mathrm{HP}_{\mathrm{t}}$ is the monthly hydropower production through the reservoir during " $\mathrm{t}$ " time-period and is in the terms of Mega-Watt-hour (MWh). The objective function mentioned above is subjected to various constraints.

The head availability in the reservoir should always be greater than or equal to the least drawdown level of the powerplant for the generation of electricity for any " $t$ " time period. This can also be put in below equation:

$\mathrm{H}_{\mathrm{t}} \geq \mathrm{MDDL}_{\mathrm{t}}$, for all $\mathrm{t}=1,2 \ldots, 12(1.3)$

Where, $\mathrm{H}_{t}$ is the average head (in meter) available in the reservoir and MDDL is the power plant's minimum drawdown level during "t" time period.

The head-storage co-relation of the reservoirfor any time period " $t$ " can be established using following arithmetical relationship:

$\mathrm{H}_{\mathrm{t}}=\mathrm{m} * \mathrm{~S}_{\mathrm{t}}+\mathrm{C}(1.4)$

The reservoir storage $\left(\mathrm{S}_{\mathrm{t}}\right)$ at any time period " $\mathrm{t}$ " should be between the range of minimum storage $\left(S_{\min }\right)$ capacity and maximum storage $\left(S_{\max }\right)$ capacity of the reservoir. Thestorage constraint has been specified as:

$S_{\text {MIN }} \leq S_{t} \leq S_{\text {MAX }}, \quad \mathrm{t}=1,2, \ldots$, (1.5)

Where, $S_{\text {MIN }}$ is the reservoir's minimum storage capacity, $S_{t}$ is the reservoir's live storage capacity during any " $t$ " time period and $S_{\max }$ is the reservoir's maximum storage capacity. While optimizingthe reservoir operation the problem of overflow comes into scenario once the maximum storage defined level of the reservoir surpasses. The constraint in mathematical form is: 
$\mathrm{O}_{\mathrm{t}}=\mathrm{S}_{\mathrm{t}+1}-\mathrm{S}_{\mathrm{MAX}}, \quad \mathrm{t}=1,2, \ldots, 12(1.6)$

And

$\mathrm{O}_{\mathrm{t}} \geq 0, \mathrm{t}=1,2, \ldots, 12(1.7)$

Where, $\mathrm{O}_{\mathrm{t}}$ is overflow through spillwayduring any " $\mathrm{t}$ " time period.

The power generation of a hydroelectric power plant during any " $t$ " time period should be equal to or less than the maximum designed power generation capacity of the powerplant.Maximum power production limit can be arithmetically represented as:

$\left(\mathrm{HP}_{\mathrm{t}}\right) \leq \mathrm{E}_{\text {MAX }}, \mathrm{t}=1,2, \ldots, 12(1.8)$

Where, $\mathrm{HP}_{\mathrm{t}}$ is the hydro-power generated (MWh) during any "t" time period, $\mathrm{E}_{\mathrm{MAX}}$ is the maximum power (MWh) that can be generated in " $\mathrm{t}$ " time period.

The released water during any time period " $t$ " from a reservoir ought to be equal-to or greater than the demand during that time period " $t$ " and is equal-to or less than the maximum carrying capacity of the penstock. The release constraint for different demands can berepresented mathematically as:

$\mathrm{D}_{\mathrm{t}} \leq \mathrm{R}_{\mathrm{t}} \leq \mathrm{C}_{\mathrm{p}}, \quad \mathrm{t}=1,2, \ldots,(1.9)$

Where, $\mathrm{D}_{\mathrm{t}}$ is the monthly demands from all the different sectors during the month " $\mathrm{t}$ ", $\mathrm{R}_{\mathrm{t}}$ is the release via reservoir for the month " $\mathrm{t}$ ", and $\mathrm{C}_{\mathrm{p}}$ is the maximum carrying capacity of the hydropower channel.

The strategy adopted for controlling flood is that, every month some free space must be allocated in reservoir to handle uncertainties.

$S_{M A X}-S_{t} \geq(F Z L-C Z L),(1.10)$
Where, $S_{M A X}$ is the storage capacity of the reservoir, St is the live storage capacity of the reservoir during any " $\mathrm{t}$ " time period, FZL is the flood zone level and CZL is the conservation zone level.

For any reservoir network the correlation between monthly varying storages can be established using thecontinuity equation. For any given " $\mathrm{t}$ " time period,below is the equation which gives relation between storage in the reservoir, inflow, releases, environmental flow and overflow (losses) through the reservoir:

$\mathrm{S}_{\mathrm{t}+1}=\mathrm{S}_{\mathrm{t}}+\mathrm{I}_{\mathrm{t}}-\mathrm{E}_{\mathrm{t}}-\mathrm{R}_{\mathrm{t}}-\mathrm{O}_{\mathrm{t}}, \mathrm{t}=1,2, \ldots 12$

Where $S_{t}$ is the storage capacity of reservoir at the beginning of month "t", $\mathrm{S}_{\mathrm{t}+1}$ is the storage capacity of the reservoir at the beginning of the month $t+1, I_{t}$ is the dependableinflow to the reservoir during the month "t", $\mathrm{R}_{\mathrm{t}}$ is the penstock release during the month " $t$ ", $E_{t}$ is the evaporation losses from the reservoir during the month " $\mathrm{t}$ " and $\mathrm{O}_{\mathrm{t}}$ is the reservoir's overflow during the month "t".

\section{RESULTS AND DISCUSSION}

In this study a reservoir optimization model characterized by various constraints (Equation 1.1-2.1)has been applied to the Maithon reservoir in order to achieve the optimal reservoir operation policy for maximizing the hydropower production potential along with fulfillment of water supply for various other purposes simultaneously.For the present study the historical data of past thirty five years (1981-2016) has been taken to obtain the magnitude of inflow to the reservoir whose probability of occurrence is equal to or in excess of a specified percentage expedience viz. 50\% (Wet),70\% (Normal) and 90\% (Dry) has been calculated and represented in graphical form in below Fig. 2.

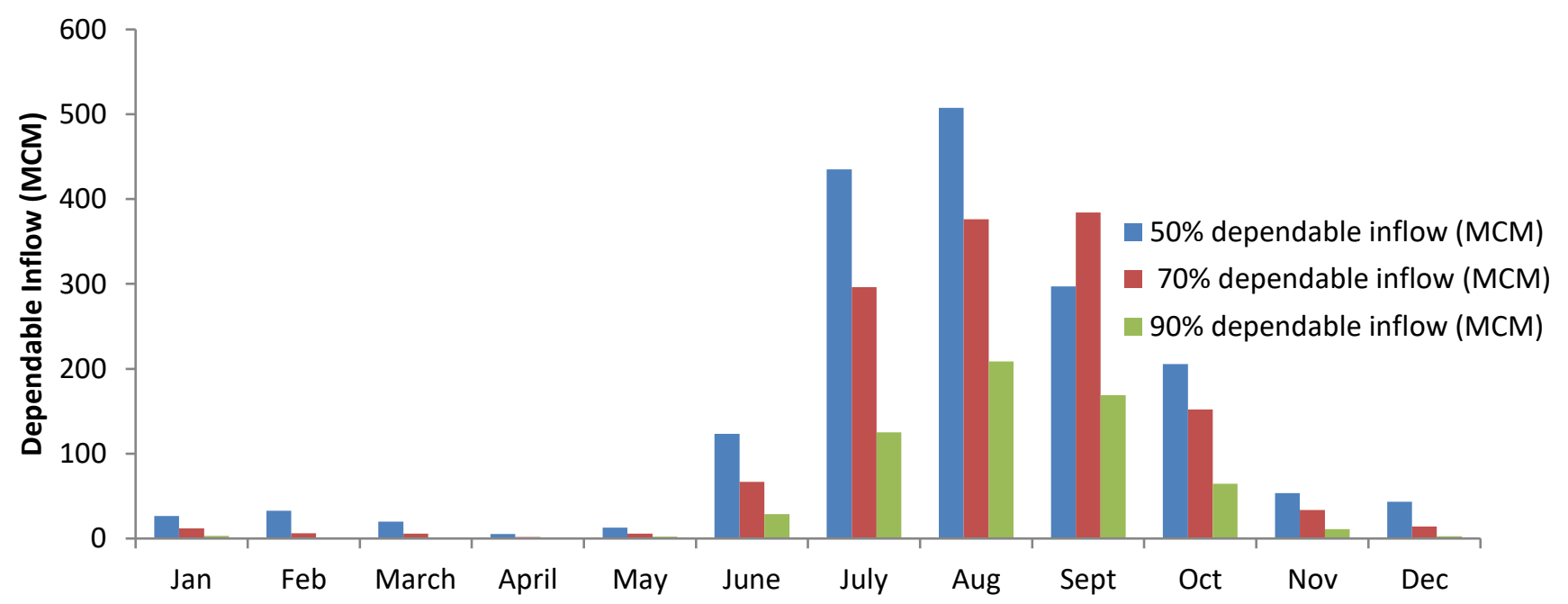

Fig. 2.Monthly dependable inflow (in MCM) for historical period (1981-2016)

Fig. 2 shows the availability of higher averageinflow in monsoon period. The month of August is observed withmaximum inflow.For planning the allocation of water resources for various purposes, it is very much essential to assess the demand of water from various sectors such as domestic, industrial, irrigation, hydropower etc.The various water demands (MCM) to be fulfilled by Maithon reservoir has been shown below in Fig. 3. 


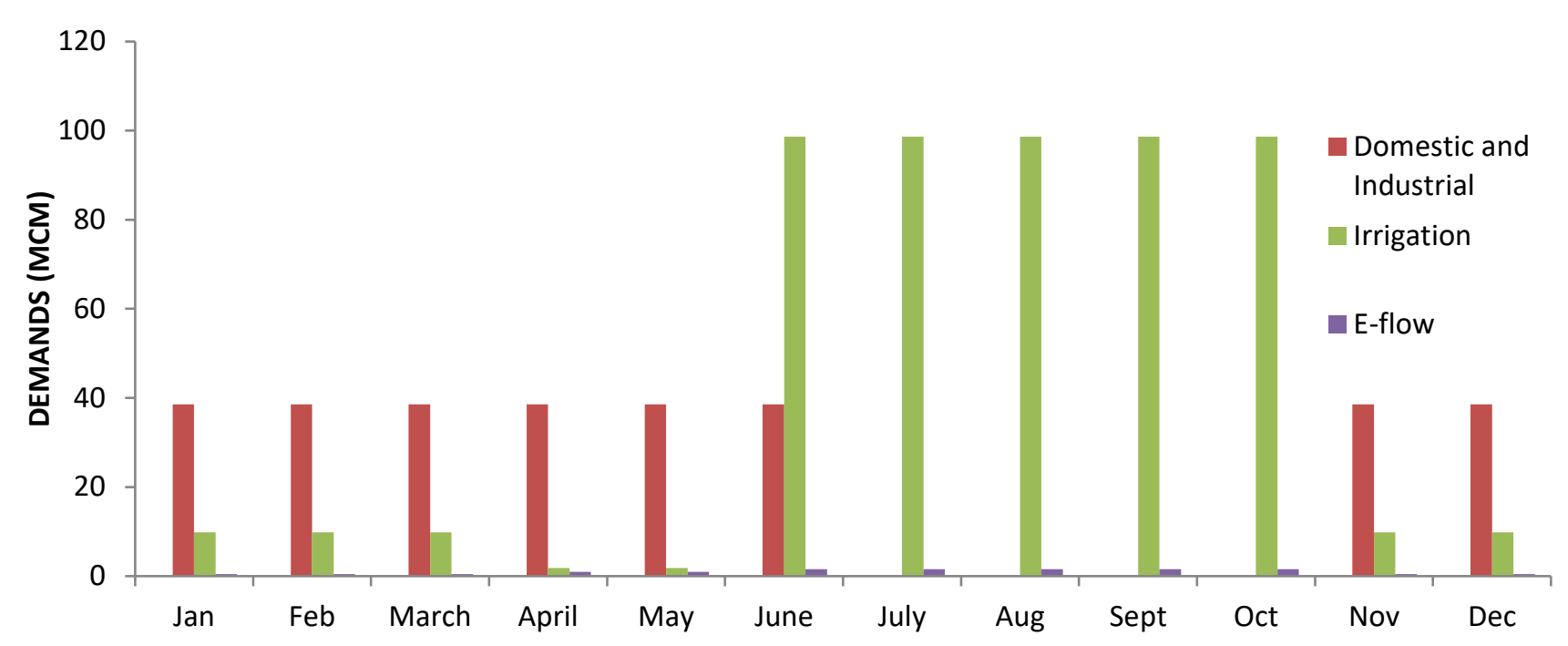

Fig.3. Total monthly demand to be fulfilled by Maithon reservoir

The results of the developed non liner programming model for the proposed scenariosunder different dependable inflow conditions are discussed in the following section.

\section{Policy Generation for Maximum Hydropower Production}

On the basis of above formulated Non-linear Programming (NLP) modelseveral policies has been generated for each dependable inflow condition by considering the fact, that percentage fulfillment of drinking water demandsand industrial water demands is $100 \%$ in all the three segments i.e. pre-monsoon (April-May), monsoon (June-October) and post-monsoon (November-March) under all the three dependable inflow condition for each policy. As, a greater amount of rainfall is received during the monsoon season and a lesser amount of water is required from irrigation sectorduring monsoon, therefore the percentage fulfillment of irrigation water demand has also been considered $100 \%$ for post-monsoon season under each policy for all the three dependable inflow conditions in all the three segments.Different polices has been generated by varying the percentage fulfillment of irrigation water demands during pre-monsoon and monsoon season under each dependable flow condition for each policy. These policies will be helpful to the reservoir operators in evaluating and analyzing the full reservoir potential of the reservoir system.
Under each dependable inflow scenario (inflow conditions) several policies have been generated and analyzed.

\section{Case I) Hydropower Generation for Different Policies} Under 50\% Dependable Inflow Conditions

Under 50\% dependable inflow condition five policies have been analyzed and the developed policies arediscussed below

According to pol-1, all the demands are fully satisfied in all the three segments except irrigation demand, which is satisfied up to $95 \%$ timesduring monsoon and pre-monsoon season. Similarly according to pol-2,all the demand are fully satisfied expect the irrigation demand,which is $85 \%$ for monsoon and pre-monsoon season. Underpol-3, which fulfills $75 \%$ demand for irrigation during pre-monsoon and monsoon, all the other demands in this policy are completely fulfilled.For proposed pol-4, 65\% irrigation demand for pre-monsoon and monsoon is considered at the same time keeping all the other demands in three segments are completely fulfilled.Inpol-5,all the demands are fully contentedexcept the irrigation demand. In this case the fulfillment of irrigation demand is $55 \%$ for pre-monsoon and monsoon season. Table-II shows the amount of hydropower generated per year under 50\% dependable inflow for five different policies.

Table-II:Hydropower generation under $50 \%$ dependable inflow

\begin{tabular}{|c|c|c|c|c|c|c|c|c|}
\hline \multirow{2}{*}{$\begin{array}{l}\text { Dependable } \\
\text { Inflow(\%) }\end{array}$} & \multirow[t]{2}{*}{ Policy } & \multicolumn{2}{|c|}{$\begin{array}{l}\text { Pre-Monsoon } \\
\text { Segment } \\
\text { (Apr - May) } \\
\end{array}$} & \multicolumn{2}{|c|}{$\begin{array}{c}\text { Monsoon Segment } \\
\text { (June - Oct) }\end{array}$} & \multicolumn{2}{|c|}{$\begin{array}{c}\text { Post- } \\
\text { MonsoonSegment } \\
\text { (Nov - March) } \\
\end{array}$} & \multirow{2}{*}{$\begin{array}{l}\text { HydropowerProduced } \\
\text { (MWh/yr) }\end{array}$} \\
\hline & & $\begin{array}{c}\text { DIWD } \\
(\%)\end{array}$ & $\begin{array}{l}\text { IRD } \\
(\%)\end{array}$ & $\begin{array}{l}\text { DIWD } \\
(\%)\end{array}$ & $\begin{array}{l}\text { IRD } \\
(\%)\end{array}$ & $\begin{array}{c}\text { DIWD } \\
(\%)\end{array}$ & $\begin{array}{l}\text { IRD } \\
(\%)\end{array}$ & \\
\hline \multirow{5}{*}{50} & 1 & 100 & 95 & 100 & 95 & 100 & 100 & 131676.95 \\
\hline & 2 & 100 & 85 & 100 & 85 & 100 & 100 & 132491.09 \\
\hline & 3 & 100 & 75 & 100 & 75 & 100 & 100 & 132659.52 \\
\hline & 4 & 100 & 65 & 100 & 65 & 100 & 100 & 133026.13 \\
\hline & 5 & 100 & 55 & 100 & 55 & 100 & 100 & 133394.42 \\
\hline
\end{tabular}

*DIWD= Drinking and industrial water demand; *IRD=Irrigation water demand 
Study reveals that, if some trade-offs in percentage fulfillment of irrigation demands could be set, the policies will results into optimized generation of hydropower. In Figure 4, segment wise total monthly power production under all the five policies for 50\% dependable inflow condition has been shown.From the figure, it is observed that under all the policies, the monsoon season segment (June to October)have resulted the maximum production due to high inflow and storage.During the pre-monsoon (April to May) season segment, the hydropower generation is very less because of the availability ofvery less amount ofinflow which results into lesser storage. Under post-monsoon (November to March) season segment the rate of power production is in the range ofmedium to high. Water stored during monsoon season can be used during this segment of the year in order to increase the power production rate.

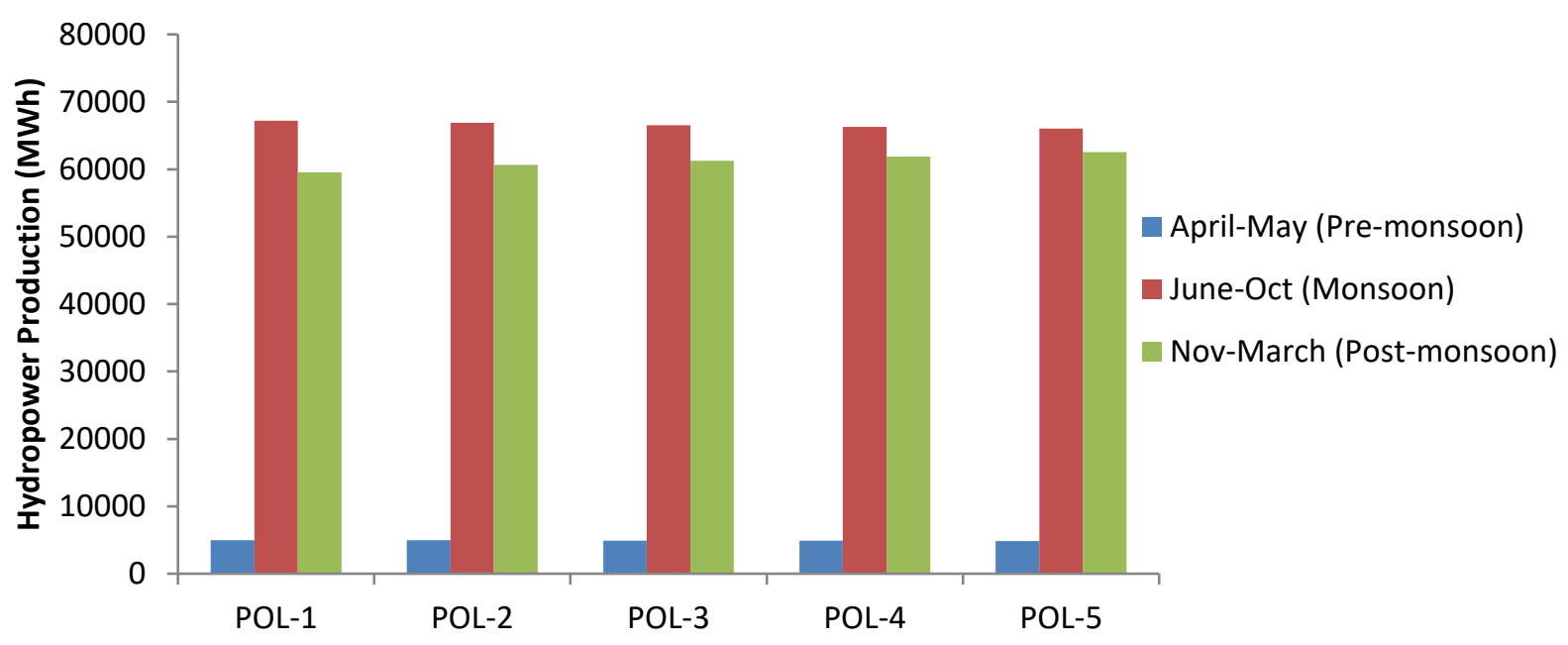

Fig.4.Segment wise hydropower generation under $50 \%$ dependable inflowcondition.

\section{Case II)Hydropower Generation for Different Policies Under 70\% dependable inflow condition}

Under 70\% dependable inflow condition 4 different policies also have been proposed anddiscussed as follows.Pol1considers the fulfillment of $45 \%$ and $85 \%$ irrigation demand for pre-monsoon and monsoonseason respectively keeping all the demands completelyfulfilled.Under pol-2, which considers the $100 \%$ fulfillment of all demands except the irrigation demand, in this scenario $35 \%$ of irrigation demand is fulfilled during monsoon season segment and $75 \%$ during pre-monsoon season.In pol-3,all the demands are fully contentedin all the three segments except irrigation demand,the percentage fulfillment of irrigation demand under this trial is $25 \%$ and $65 \%$ for monsoon and premonsoon season. According to pol-4,fulfillment of irrigation demand during pre-monsoon and monsoon season are $15 \%$ and $55 \%$ respectively all and other demands are entirelyfulfilled.Table-III shows the amount of hydropower generated per year under $70 \%$ dependable inflow for four feasible policies.

Table- III: Hydropower generation under $70 \%$ dependable inflow

\begin{tabular}{|c|c|c|c|c|c|c|c|c|}
\hline \multirow{2}{*}{$\begin{array}{l}\text { Dependable } \\
\text { Inflow (\%) }\end{array}$} & \multirow[t]{2}{*}{ Policy } & \multicolumn{2}{|c|}{$\begin{array}{c}\text { Pre-Monsoon } \\
\text { Segment } \\
\text { (Apr - May) } \\
\end{array}$} & \multicolumn{2}{|c|}{$\begin{array}{c}\text { Monsoon Segment } \\
\text { (June - Oct) } \\
\end{array}$} & \multicolumn{2}{|c|}{$\begin{array}{l}\text { Post-Monsoon } \\
\text { Segment } \\
\text { (Nov - March) } \\
\end{array}$} & \multirow{2}{*}{$\begin{array}{l}\text { Hydropower } \\
\text { Produced } \\
\text { (MWh/yr) }\end{array}$} \\
\hline & & $\begin{array}{c}\text { DIWD } \\
(\%)\end{array}$ & $\begin{array}{l}\text { IRD } \\
(\%) \\
\end{array}$ & $\begin{array}{c}\text { DIWD } \\
(\%)\end{array}$ & $\begin{array}{l}\text { IRD } \\
(\%)\end{array}$ & $\begin{array}{c}\text { DIWD } \\
(\%)\end{array}$ & $\begin{array}{l}\text { IRD } \\
(\%)\end{array}$ & \\
\hline \multirow{4}{*}{$70 \%$} & 1 & 100 & 45 & 100 & 85 & 100 & 100 & 99281.96 \\
\hline & 2 & 100 & 35 & 100 & 75 & 100 & 100 & 100947.75 \\
\hline & 3 & 100 & 25 & 100 & 65 & 100 & 100 & 101921.93 \\
\hline & 4 & 100 & 15 & 100 & 55 & 100 & 100 & 103015.14 \\
\hline
\end{tabular}

Under $70 \%$ dependable inflow condition, segment wise total monthly power production is presented in Fig. 5. In this figure this is shown that, the maximum production of hydropower is during the monsoon season segment (same as in case of $50 \%$ dependable inflow condition) due to higher inflow and storage.Under this inflow condition the hydropower generation during the pre-monsoon season segment is almost same or constant in all the policies. For the post-monsoon season segment, the variation in generation of hydropower is also very less. the scenario this can be concluded that during the monsoon season a greater amount of storage can be made in order to use it for hydropower generation during the Non-monsoon period. 


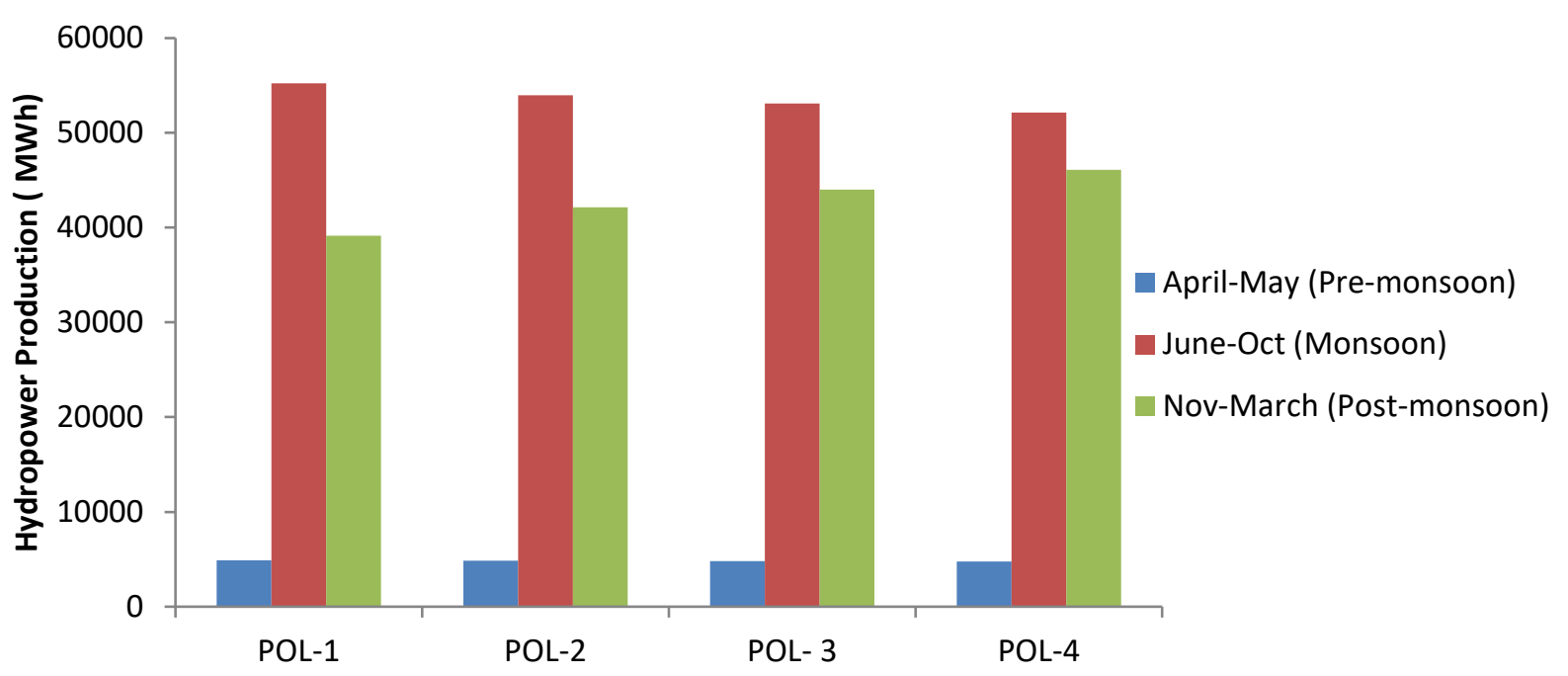

Fig. 5.Segment wise hydropower generation under $\mathbf{7 0} \%$ dependable inflowcondition

\section{Case III)Hydropower Generation for Different Policies}

\section{Under 90\% Dependable Inflow Condition}

For $90 \%$ dependable inflow under pol-1, the fulfillment of irrigation demand in all the three segments is zero percent considering the fulfillment of other demands as $80 \%$ in all the three segments.

Table-IV:Hydropower generation under $90 \%$ dependable inflow

\begin{tabular}{|c|c|c|c|c|c|c|c|c|}
\hline \multirow{2}{*}{$\begin{array}{l}\text { Dependable } \\
\text { Inflow (\%) }\end{array}$} & \multirow[t]{2}{*}{ Policy } & \multicolumn{2}{|c|}{$\begin{array}{l}\text { Pre-Monsoon } \\
\text { Segment } \\
\text { (Apr - May) }\end{array}$} & \multicolumn{2}{|c|}{$\begin{array}{c}\text { Monsoon Segment } \\
\text { (June - Oct) } \\
\end{array}$} & \multicolumn{2}{|c|}{$\begin{array}{l}\text { Post-Monsoon } \\
\text { Segment } \\
\text { (Nov - March) } \\
\end{array}$} & \multirow{2}{*}{$\begin{array}{l}\text { Hydropower } \\
\text { Produced } \\
\text { (MWh/yr) }\end{array}$} \\
\hline & & $\begin{array}{c}\text { DIWD } \\
(\%)\end{array}$ & $\begin{array}{l}\text { IRD } \\
(\%) \\
\end{array}$ & $\begin{array}{c}\text { DIWD } \\
(\%)\end{array}$ & $\begin{array}{l}\text { IRD } \\
(\%) \\
\end{array}$ & $\begin{array}{c}\text { DIWD } \\
(\%)\end{array}$ & $\begin{array}{l}\text { IRD } \\
(\%)\end{array}$ & \\
\hline 90 & 1 & 80 & 0 & 80 & 0 & 80 & 0 & 61782.77 \\
\hline
\end{tabular}

For $90 \%$ dependable inflow only one policy was feasible as the flow availability under this dependable inflow condition is very less, therefore the fulfillment of respective demands under this policy has also been considered as very poor. Hydropower generation corresponding to this dependable inflow condition has been shown in below figure.

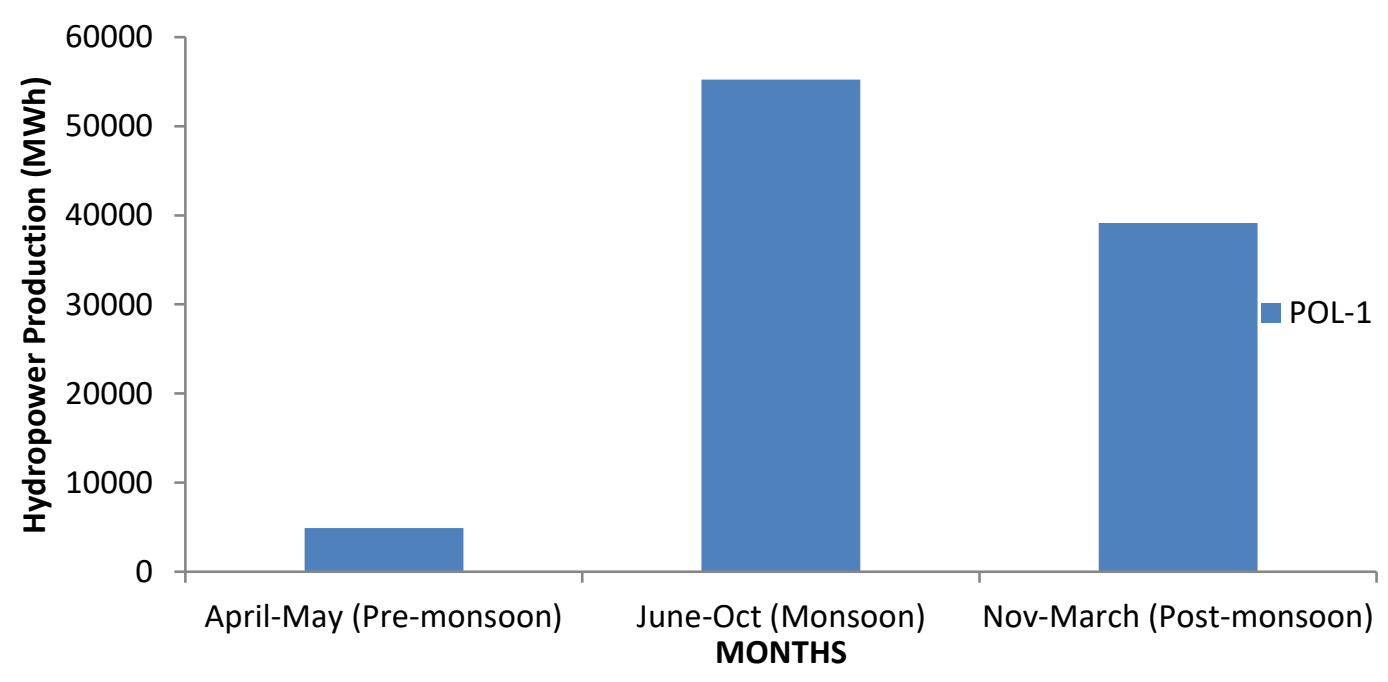

Fig. 6.Segment wise hydropower generation under $90 \%$ dependable inflow condition 


\section{E.Annual Power Production}

The total annual hydroelectric power production from various policies under the $50 \%, 70 \%$ and $90 \%$ dependable inflow conditions are shown in below Table-V.Major observations from the Table- $\mathrm{V}$ is that hydropower generation is indirectly proportional to the inflow dependability. The reason behind this is that with increase in dependability level the quantity of inflow decreases. Also, the various scenarios discussed shows that, with increase in the irrigation release the power production decreases. In order to resolve the problem of such conflicting objectives when eitherof the objective is not incidental, some trade-offs could be set in order the find out the optimum policy for hydropower generation. The combined annual hydropower generation corresponding to the policies generated under different inflow conditions has been tabulated below:

Table-V:Annual hydropower generation potential of various policies under different inflow conditions

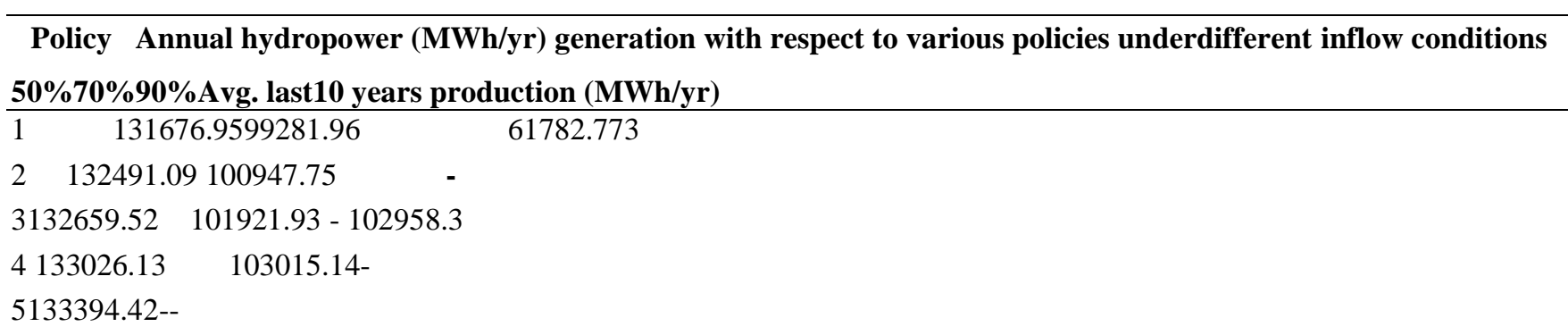

\section{F. Firm Power Production}

Firm power is basically the power that is available with $100 \%$ reliability. It is generated with certainty without interruption at site. In this study, the optimized value of firm power for all the three different dependable inflow conditions i.e., 50\%, 70\% and 90\% have been computed.
For computing firm power a trial value of firm power, which can be computed each year $100 \%$ of the time has been assumed. This assumed value is adopted as a constraint in the LINGO hydropower optimization model. The firm power value for all the respective inflow conditions has been shown in following table-

Table-VI:Firm power corresponding to different dependable inflow conditions

\begin{tabular}{cc}
\hline Dependable Inflow & Firm Power (MW) \\
\hline $50 \%$ & 5.773 \\
$70 \%$ & 3.421 \\
$90 \%$ & 2.647 \\
\hline
\end{tabular}

\section{G. Storage CurveUnder Various Policies}

The storage levels that should be maintained at the end of the any month "t"for the generation of maximum hydropower from various dependable inflow conditions i.e., $50 \%, 70 \%$ and $90 \%$ under various policies has been discussed in following section. On the basis of the various policies generated, the storage at the end of the month that is to be maintained for optimal hydropower generation has been shown in the figure below. For 50\% dependable inflow the maximum storage has been spotted during the month of
September. This is due to the availability of greater inflow during the monsoon season. Along with this the release constraint during the period of this month has also been found to be less because of the lesser demand from various sectors, resulting into greater storage. Analysis shows that, the reservoir generally reaches to the level of maximum storage during the season of monsoon (June-October). Fig. 7 highlightsthe end month storage corresponding to 50\% dependable inflow scenario.

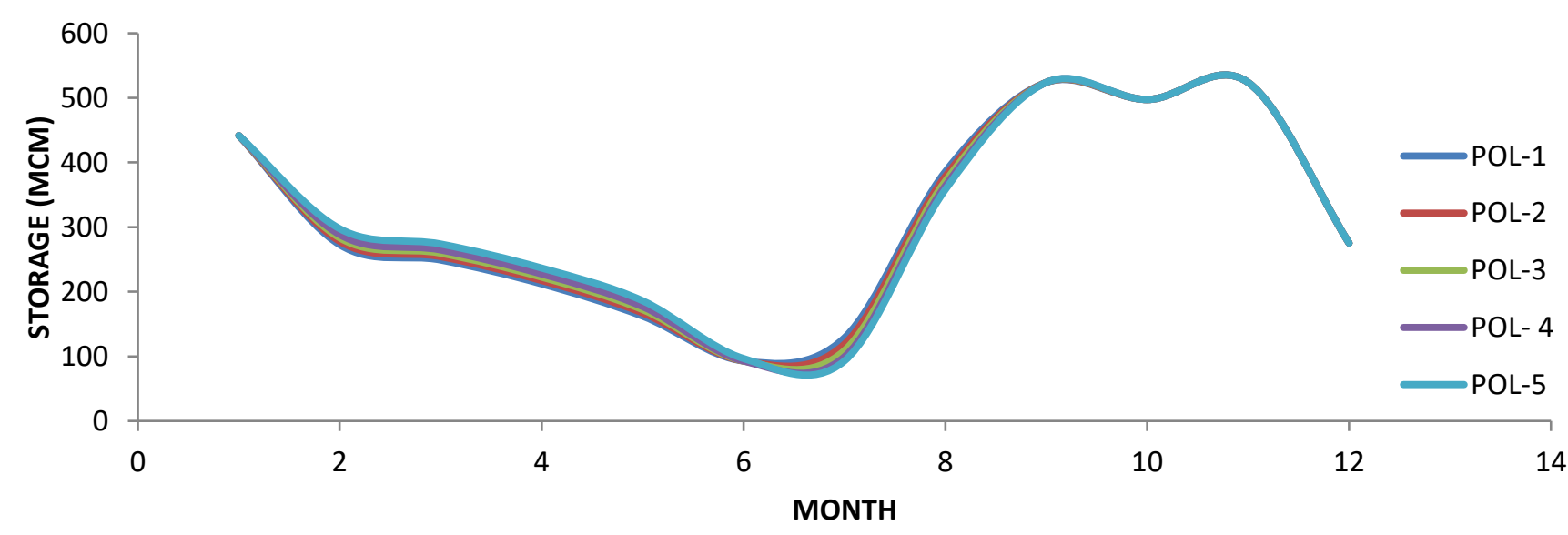

Fig. 7End month storages under $50 \%$ dependable inflow 
After analyzing all the policies this has beenconcluded that the storage of the reservoir is in decreasing trend during non-monsoon period due to very less inflow and release made from carry over storage only. The resulted final storage for $70 \%$ and $90 \%$ dependable inflow conditions has been shown in Fig.8 and Fig. 9 respectively.

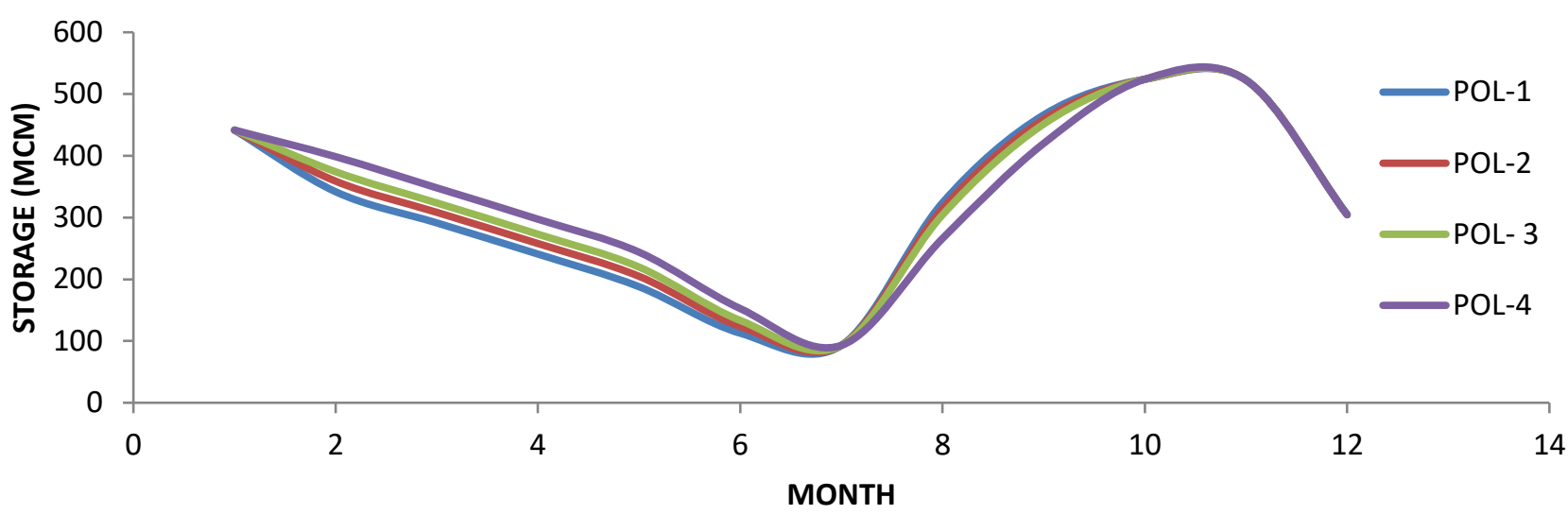

Fig. 8.End month storage under $70 \%$ dependable inflow

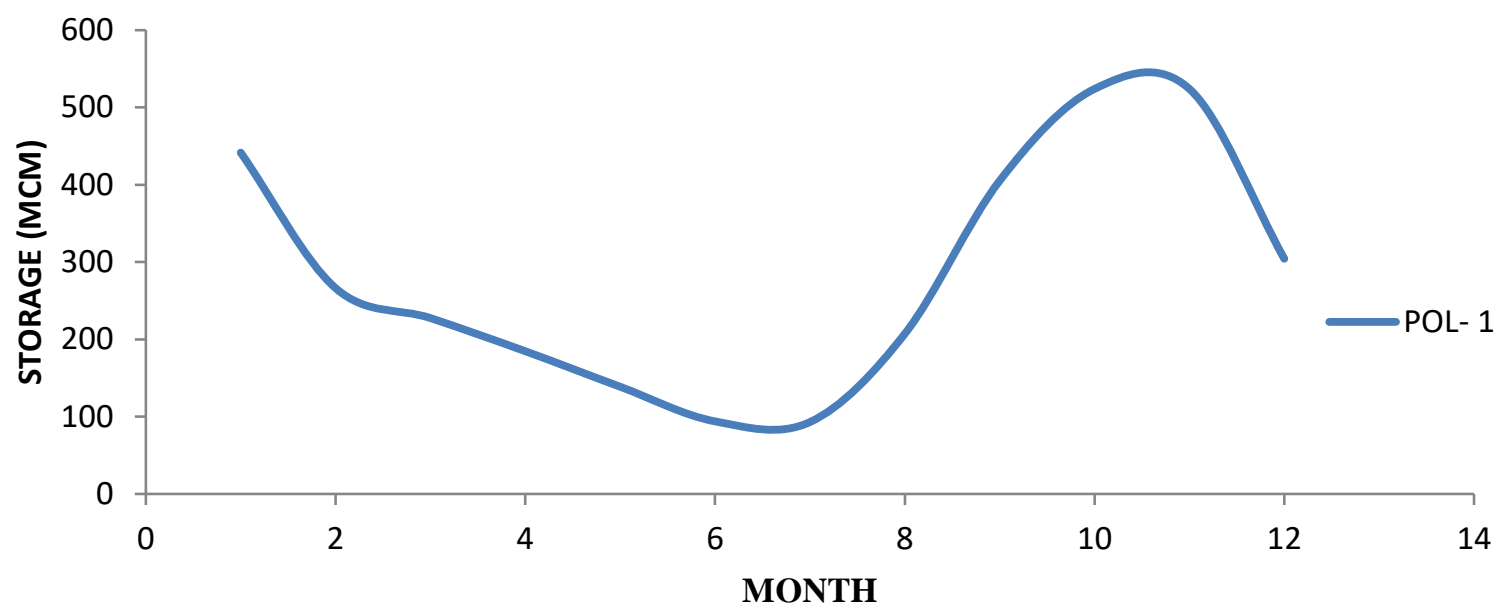

Fig.9.End month storage under $90 \%$ dependable inflow.

\section{CONCLUSION}

This study suggests the effective application of constrained Non-linear Programming model by using the LINGO integrated framework for obtaining the efficient operating policy of Maithon multi-purpose reservoir system. Hydroelectric power produced in this study, under different dependable inflow conditions (50\%, 70\% and $90 \%$ dependable inflow) were compared with the existing average hydropower generation of last 10 years. It was observed that, the hydropower generations obtained under the different inflow scenarios are optimized compared to the existing policies generation.Among all the three dependable inflow conditions discussed above, the hydropower generation under $50 \%$ dependable inflow is having maximum inflow resulting into maximum power generation.Under different scenarios, policy 5, under $50 \%$ dependable inflow scenario has resulted the maximum power production of $133394.428 \mathrm{MWh} / \mathrm{yrkeeping}$ the percentage fulfillment of all the demands at $100 \%$ and irrigation demand at 55\%. The study reveals that there is good scope for further research and development in this field.

\section{REFERENCES}

1. Anand, J., Gosain, A. K., \&Khosla, R. (2018). Optimisation of multipurpose reservoir operation by coupling Soil and Water Assessment Tool (SWAT) and Genetic Algorithm for optimal operating policy (Case study: Ganga River Basin). Sustainability, 10, 1660;doi:10.3390/su10051660.

2. Arunkumar, R., \&Jothiprakash, V. (2012). Optimal reservoir operation for hydropower generation using Non-linear Programming Model. Journal of the Institution of Engineers, 93(2), 111-120.

3. Barros, M.T.L., Tsai, F., Lopes, J.E.G., \&Yeh, W. (2003). Optimization of large-scale hydropower system operations. Journal of Water Resources Planning and Management, 129(3), 178-188.

4. Barros, M.T.L., Zambon, R.C., Lopes, J.E.G., Barbosa, P.S.F., Francto, A.L.F., \&Yeh, W.W-G. (2009). Impact of the upstream storage reservoir on itaipu hydropower plant operation. Proc. World Environmental and Water Resources Congress 2009 Great Rivers, ASCE, Kanas City, 4938-4946.

5. Chang, F.J., Lai, J.S. \& Kao, L.S. (2003). Optimization of operation rule curves and flushing schedule in a reservoir. Hydrological Process, 17, 1623-1640.

6. Guariso, G., Rinaldi, S. \&Soncini-Sessa, R. (1986). The management of Lake Como: A multi-objective analysis. Water Resources Research, 22(2), 109-120.

7. Lingo User Guide. (Lindo systems, Inc., Illinois, 2011), p. 834 
8. Liu, S., Wang, J., \& Liu, Z. (2008). Short- term hydropower optimal scheduling of multi-reservoir system using a decomposition approach. Forth International Conference on Natural computation, IEEE, 565570.

9. M.H, V. (2016). Simulation and modeling of reservoir operation. International Journal of Latest Trends in Engineering and Technology, 7, 325-327.

10. Majumdar, P.P. \&Nirmala, B. (2007). A Bayesian stochastic optimization model for a multi-reservoir hydropower system. Water Resources Management, 21(9), 1465-1485.

11. Mays, L.W. \& Tung, Y. K. (1992). Hydro-systems Engineering \& Management McGraw Hill. United States of America.

12. Mossavian, S. A. A., Ghafari, A., \&Abdi, N. (2008). Nonlinear multiobjective optimization for control of hydropower plants network. ASME International Conference on Advanced Intelligent Mechatronics, IEEE, 1278-1283.

13. Oliveira, R., \&Loucks, D. P. (1997). Operating rules for multireservoir systems. Water Resources Research, 33(4), 839-852.

14. Parsa, M. S. (2017). Optimal reservoir operation of Karun 4 reservoir by Linear Programming. International Academic Journal of Science and Engineering, 4(1), 110-120.

15. Rani, D., \& Moreira, M.M. (2009). Simulation-optimization modelling: a survey and potential application in reservoir systems operation. Water Resources Planning and Management, 24(6), 11071138

16. Sharif, M., \&Swamy, V.S. (2014). Development of LINGO based optimization model for multi-reservoir system operation. International Journal of Science and Technology, 4(2), 126-138.

17. Si, Y., Li, X., Yin, D., Liu, R., Wei, J., Wei, J., Huang \& Y. Wang, G. (2018). Evaluating and optimizing the operation of hydropower system in the Upper Yellow River: A general LINGO- based integrated framework. Plos One, 13(1).

18. Singh, A. (2012). An overview of the optimization modelling applications. Journal of Hydrology, https://doi.org/10.1016/j.jhydrol.2012.08.004.

19. Wurbs, R. (1993). Reservoir-system simulation and optimization models. Journal of Water Resources Planning and Management, ASCE 119(4), 455-472 .

20. Yeh, W.W.G. 1985. Reservoir management and operation models: a state-of-the-art review. Water Resources Research, 21(12), 1797-1818.

\section{AUTHORS PROFILE}

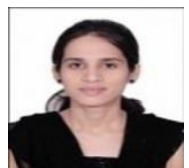

PRITI SAGAR is a PhD Research Scholar inDepartment of WEM at the Central University of Jharkhand, Ranchi, India.She is Presently pursuing her $\mathrm{Ph}$. D under the guidance of Dr. Prabeer Kumar Parhi. She is working in the field of Reservoir Operations. She may be contacted atsagarpriti68@gmail.com.

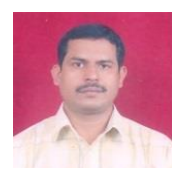

Dr. PRABEER KUMAR PARHIis an Assistan

Professor inDepartment ofWEM at the Central University of Jharkhand, Ranchi, India. He received his PhD (2007) in Water Resources Planning and Management, from I.I.T Roorkee.He has published number of research papers in international, national journals of esteemed repute. His prominent research interests revolve around Reservoir design and operation, Water resources systems, Mathematical modeling of surface-flow, flood forecasting, and other fields of Hydrology. His e-mail address is prabeer11@yahoo.co.in.

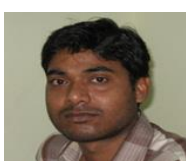

Dr. BIRENDRA BHARTI is an Assistant Professor inDepartment of WEM at the Central University of Jharkhand, Ranchi, India. He received his $\mathrm{PhD}$ (2016) in Water Resources Planning and Management, from I.I.T Roorkee.He has published number of research papers in international, national journals of esteemed repute.

His prominent research interests revolve around Remote sensing and GIS for water resources planning and management, Ground water hydrology, Irrigation water management and other fields of Watershed.. His e-mail address is birendrabharti@gmail.com. 